\title{
PESERTA DIDIK DI TAMAN KANAK-KANAK SEBAGAI FAKTOR DETERMINAN DALAM PENDIDIKAN DI MASA PANDEMI COVID-19
}

\author{
Eka Damayanti \\ Universitas Islam Negeri Alauddin Makassar, \\ eka.damayanti@uin-alauddin.ac.id \\ Ratika Nengsi \\ Universitas Muslim Indonesia, \\ ratika.nengsi@umi.ac.id \\ Hasmiati \\ Institute Agama Islam Muhammadiyah Sinjai, \\ miaelbugis@gmail.com \\ Sudirman P \\ Institute Agama Islam Muhammadiyah Sinjai, \\ sudirmanuinsuka@gmail.com
}

\begin{abstract}
Abstrak
Artikel ini bertujuan untuk menggambarkan posisi peserta didik di Taman Kanak-kanan sebagai faktor determinan dalam pendidikan dan sikap peserta didik selama pandemi Covid-19. Artikel ini disusun berdasarkan penelitian pustaka (library research) dengan pengumpulan data menggunakan data dokumentasi yang berasal dari buku-buku atau jurnal atau terbitan-terbitan terdahulu yang relevan dalam fokus kajian. Analisis data menggunakan teknik analisis deskriptif. Hasil penelitian menunjukkan posisi peserta didik tingkat Taman Kanak-kanak (TK) sangat penting karena pada tahap ini merupakan pondasi awal dalam membentuk karakter dan pengetahuan awal peserta didik secara formal dimana tuntutan pendidikan difokuskan pada aspek pengembangan: (1) nilai agama dan moral; (2) fisik dan motorik; (3) kognitif; (4) bahasa; (5) sosial dan emosi; (6) seni. Temuan dari penelitian ini merekomendasikan kepada pendidik untuk menghadirkan pembelajaran yang menyenangkan (joyful learning) selama pembelajaran daring di masa pandemic Covid-19 agar peserta didik di Taman Kanak-kanan dapat maksimal aspek perkembangannya.
\end{abstract}

Kata Kunci: Anak Usia Dini, Determinan Pendidikan, Pembelajaran Daring

\begin{abstract}
This article aims to describe the position of students in Kindergarten as a determining factor in education and student attitudes during the Covid-19 pandemic. This article was compiled based on library research using relevant documentation data from books or journals or previous publications to the focus of the study. Data analysis used descriptive analysis techniques. The
\end{abstract}


results of the study show that the position of Kindergarten level students is most important due to the ages as the initial foundation in forming the character and initial knowledge of students formally where educational demands are focused on aspects of development: (1) religious and moral values; (2) physical and motor; (3) cognitive; (4) language; (5) social and emotional; (6) art. The findings from this study recommend that educators present fun learning (joyful learning) during online learning during the Covid19 pandemic so that students in Kindergarten can maximize their developmental aspects.

Keyword: Early Childhood, Determinants of Education, Online Learning

\section{PENDAHULUAN}

Anak yang belajar dalam institusi pendidikan disebut sebagai peserta didik. Belajar tidak lepas dari kehidupan manusia, karena aktivitas belajar inilah yang membedakan antara manusia dengan makhluk lainnya. Aktivitas belajar khususnya di tingkat Taman Kanak-kanak atau Pendidikan Anak Usia Dini (PAUD) dapat membantu anak dalam mengembangkan potensinya baik fisik maupun psikis karena pada dasarnya setiap manusia yang lahir telah memiliki potensi untuk dikembangkan. Menurut Sudarwan Danim (2013) bahwa aspek fisik dan psikis dalam peserta didik tidak dapat dipisahkan karena mempunyai hubungan yang saling terjalin anara satu dengan yang lain, jika salah satu aspek mengalami kesulitan misalnya fisiknya maka akan mengganggu psikis (emosionalnya).

Oemar Hamalik mengemukakan bahwa peserta didik merupakan salah satu komponen yang sangat penting dalam pengajaran, di samping faktor guru, tujuan dan metode pengajaran (Danim, 2013). Peserta didik sebagai individu yang mempunyai sejumlah karakteristik diantaranya: (1) Peserta didik merupakan individu dan memiliki potensi fisik dan psikis yang memiliki keunikan; (2) Peserta didik adalah individu yang berkembang; (3) Peserta didik merupakan individu dan membutuhkan bimbingan individual dan harus diperlakukan manusiawi; (4) Peserta didik adalah individu yang mempunyai kemampuan untuk mandiri (Desmita, 2009).

Peserta didik dalam pendidikan sangat penting posisinya, meskipun di tingkat Taman Kanak-kanak (TK)/PAUD yang diketahui sebagai tingkat paling awal dalam pendidikan formal. Hal itu terjadi karena pada dasarnya anak yang dilahirkan di dunia ini telah dibekali potensi akal untuk belajar dan mencari tahu. Hasan AlBanna mengungkapkan manusia terdiri tiga unsur pokok, yakni jasmani atau badan, akal dan hati (qalb). Akal berfungsi sebagai alat untuk berfikir (Susanto, 2009). Hal yang sama diungkapkan oleh Al-Maududi (dalam Susanto, 2009), manusia adalah hamba Allah yang diciptakan dengan dibekali berbagai macam potensi, kemampuan atau sifat dasar yaitu As-Sam'u, Al-Bashar, dan Al-Fuad. AlFuad atau akal pikiran, berarti membersihkan dari segala keraguan dan memurnikannya. Dengan akal yang dimiliki, manusia juga dapat menemukan 
berbagai macam ilmu pengetahuan sehingga dapat menjadi khalifah di muka bumi.

Al-Ghazali mengungkapkan bahwa akal merupakan salah satu dimensi fitrawi terpenting pada diri manusia karena akal sebagai alat berpikir telah memberi andil besar terhadap alur kehidupan manusia (Nasution dalam Fuadi, 2013). Jiwa manusia terdiri dari 5 dimensi atau potensi, yakni (a) potensi berfikir ilmiah atau mencari kebenaran; (b) potensi moralitas atau berbuat baik; (c) potensi religious atau beragama atau beribadah; (d) potensi keindahan atau seni; dan (e) potensi berkreasi atau menghasilkan karya sebagai wujud aktualisasi diri (Mutahhari, 2005). Oleh karena itu, artikel ini hadir dengan fokus pada kajian posisi penting peserta didik dalam pendidikan dan sikap peserta didik selama pandemi Covid-19.

\section{METODE PENELITIAN}

Artikel ini disusun berdasarkan penelitian pustaka atau Library Research dengan mengumpulkan data dengan menggunakan literatur yang relevan dengan fokus penelitian. Teknik pengumpulan data menggunakan dokumentasi dari datadata dilapangan yang diambil orang lain dan sudah ada dalam buku-buku atau jurnal atau terbitan-terbitan terdahulu sehingga sumber data yang peneliti gunakan berupa sumber data sekunder. Adapun data sekunder dalam penelitian ini adalah dokumen atau arsip berupa buku, jurnal, hasil penelitian (skripsi), dan artikel yang mendukung penelitian.

Setelah melakukan pengumpulan data, selanjutnya dilakukan analisis data yang telah diperoleh sebelumnya dengan tujuan untuk menyusun dan menginterpretasikan data yang sudah diperoleh. Adapun teknik analisis data yang digunakan dalam penelitian ini yaitu teknik analisis deskriptif yang dikemukakan oleh Milles dan Huberman yang terdiri dari tiga kegiatan, yaitu reduksi data, display (penyajian data) dan verifikasi (menarik keimpulan). Sedangkan pengujian keabsahan data dilakukan dengan peningkatan ketekunan dan penggunaan bahan referensi.

\section{HASIL DAN PEMBAHASAN \\ Posisi Penting Peserta Didik dalam Pendidikan}

Peserta didik khususnya di tingkat Taman Kanak-kanak menduduki posisi yang sangat penting dalam pendidikan. Tanpa adanya peserta didik, proses pendidikan tidak mungkin bisa terlaksana. Terlebih lagi di tingkat Taman Kanakkanak dimana pondasi pembentukan karakter sangat menentukan saat anak dewasa kelak. Dalam pendidikan anak usia dini, proses yang dijalani anak beragam sesuai dengan potensi individualnya masing-masing. Terlebih jika dibandingkan dengan tingkat pendidikan diatasnya: SD sampai perguruan tinggi. Menurut Samsul Nizar mengemukakan bahwa peserta didik bukan merupakan miniature orang dewasa. Melainkan, peserta didik memiliki dunianya sendiri. Serta peserta didik memiliki diferensiasi periodesasi dalam perkembangan dan kebutuhannya (Abdul 
et al., 2014). Karena kunci utama dalam kegiatan sebuah pendidikan adalah peserta didiknya. Peserta didik memegang peranan posisi pusat dalam proses pembelajaran. Dalam kenyataannya peserta didiklah yang menjadi pokok persoalan dan sebagai tumpuan perhatian.

Beberapa hal yang menunjukkan posisi penting peserta didik dalam pendidikan. Pertama, posisi sentral yang di duduki oleh peserta didik merupakan terminal akhir dari proses pendidikan agar menjadikan peserta didik sebagai manusia yang memiliki bekal ilmu, iman dan amal. Kedua, demikian strategis dari posisi peserta didik dalam pendidikan, sehingga semua yang berkaitan dengan kebijkanan ataupun pengembangan proses pendidikan harus melihat posisi peserta didik secara menyeluruh. Ketiga, dalam menentukan suatu kebijakan ataupun pengembangan proses pendidikan harus melihat posisi anak, jangan sampai terjadi pembaharuan ataupun modernisasi pendidikan yang justru meletakkan posisi peserta didik pada sub-ordinatnya dalam konteks situasi proses belajar mengajarnya. Keempat, segala aktivitas pendidikan harus diarahkan untuk membentuk kepribadian dan tauhid peserta didik sebagai ultimate goals yang harus tercapai.(Muhammad, 1997)

Meski dalam kenyataannya terkadang proses pendidikan yang dilaksungkan nampak belum sepenuhnya mampu mengoptimalkan pengembangan kemampuan pada peserta didik. Bahkan tidak jarang ditemukan dalam proses pendidikan justru menggiring anak untuk bersikap tidak sesuai dengan apa yang dipikirkannya. Selain pengembangan potensi, pendidikan di TK juga berfungsi untuk mewariskan nilai-nilai kepada peserta didik dan menjadikan mereka terampil untuk belajar menyelesaikan tuntutan perkembangan selanjutnya.

Berbicara mengenai aspek pengembangan peserta didik, tidak dapat terlepas dari perubahan yang terjadi pada peserta didik. Perubahan tersebut terjadi melalui kegiatan belajar (behaviour change and knowledge) yang pada intinya akan mewujudkan kecakapan baru. Sebagaimana yang dikemukakan oleh Bloom bahwa belajar membawa perubahan pada tiga aspek atau biasa juga dikenal sebagai ranah kompetensi peserta didik, yakni kognitif, afektif, dan psikomotorik (Nata, 2009; Sudjana, 2009; Uno, 2006). Terlebih dengan tuntutan zaman yang semakin berubah maka kualitas pendidikan harus ditingkatkan dengan dahsyatnya perkembangan ilmu pengetahuan di era global saat ini (Septikasari \& Frasandy, 2018). Dalam era globalisasi atau dikenal sebagai abad 21, peserta didik diharuskan menguasai berbagai keterampilan agar dapat bersaing secara nasional maupun internasional, yakni Four C: Critical thinking, communication, collaboration, and creativity (Kompasiana, 2019).

Secara khusus ditingkat TK tuntutan pendidikan difokuskan pada aspek pengembangan: (1) nilai agama dan moral; (2) fisik dan motorik; (3) kognitif; (4) bahasa; (5) sosial dan emosi; (6) seni (Menteri Pendidikan dan Kebudayaan Republik Indonesia, 2014). Dalam perspektif pendidikan Islam, yang terpenting dari 
kesemua focus pengembangan anak usia dini itu adalah untuk semakin membantu anak menyadari tujuan penciptaannya. Sebagaimana Firman Allah SWT dalam QS al Nahl/16: 78 yang berbunyi “Dan Allah mengeluarkan kami dari perut ibumu dalam keadaaan tidak mengetahui sesuatupun dan dia memberi kamu pendengaran, penglihatan dan hati, agar kamu bersyukur".

\section{Sikap Peserta Didik Dimasa Pandemi Covid-19}

Peserta didik merupakan kunci utama keberhasilan belajar, selama melakukan proses pembelajaran sikap peserta didik akan menentukan hasil dari pembelajaran yang akan mempengaruhi dalam belajar. Sikap yang salah akan membuat peserta didik tidak peduli lagi untuk belajar, akibatnya tidak akan terbentuk suasana belajar yang kondusif (Abrizah, 2021). Terlebih lagi di tingkat Taman Kanak-kanak yang sangat membutuhkan perhatian khusus dalam pembelajaran online.

Adanya Covid-19 mengharuskan peserta didik untuk berkegiatan seperti bermain dan belajar dari rumah sehingga membuat anak merasa bosan. Hasil penelitian Purwanto et al. (2020) menjelaskan bahwa beberapa dampak yang dirasakan oleh anak-anak selama pandemi yaitu: (1) mereka diharuskan belajar jarak jauh tanpa sarana dan prasarana memadai di rumah, (2) metode pembelajaran jarak jauh membuat anak-anak perlu waktu untuk beradaptasi dan mereka menghadapi perubahan baru yang secara tidak langsung akan mempengaruhi daya serap belajar mereka, (3) sekolah diliburkan terlalu lama membuat anak-anak jenuh, dan (4) anak-anak kehilangan jiwa sosialnya karena mereka tidak bisa dan hanya berinteraksi dengan orang di rumah sehingga interaksi dengan orang di luar rumah menjadi berkurang.

Survei yang dilakukan oleh Kapasia et al. (2020) menemukan bahwa selama pembelajaran daring, peserta didik menghadapi berbagai tekanan, stres serta kendala pada fasilitas belajar, seperti halnya gawai dan koneksi internet. Selain itu, Duraku dan Hoxha (2020) dalam penelitiannya juga menemukan bahwa peserta didik yang tidak termotivasi mengikuti pembelajaran daring adalah peserta didik yang menunjukkan stres tergolong tinggi. Hal inilah yang menjadi tantangan bagi para pendidik untuk dapat merancang perangkat pembelajaran yang dapat disesuaikan dengan kondisi yang ada serta disukai oleh peserta didik sehingga tidak menjadi beban yang dapat menimbulkan adanya tekanan dan stres.

Umar dan Nursalim (2020) menyimpulkan bahwa dampak yang dirasakan oleh siswa selama pandemi Covid-19 yaitu: (1) siswa menjadi kesulitan untuk beradaptasi dalam mengikuti kegiatan belajar mengajar secara jarak jauh; (2) Siswa perlu memenuhi kebutuhan fasilitas pendukung kegiatan belajar mengajar jarak jauh dimana hal ini tidak dapat dilakukan oleh semua siswa karena faktor ekonomi keluarga; (3) siswa perlu untuk belajar tentang menggunakan fasilitas internet, laptop, dan smartphone sebagai sarana pembelajaran selama mengikuti 
kegiatan belajar mengajar jarak jauh; (4) siswa lebih mudah merasa jenuh. Hal ini disebabkan karena tidak banyaknya proses interaksi yang dilakukan; dan (5) selama mengikuti kegiatan belajar mengajar jarak jauh, siswa menjadi lebih banyak memiliki tugas.

Dampak yang dirasakan peserta didik tidak bisa diabaikan. Oleh karena itu, peserta didik perlu merancang pembelajatran yang menyenangkan. Menurut Saifuddin (2014) pembelajaran yang menyenangkan merupakan proses pembelajaran yang menggunakan metode atau cara tertentu yang membuat peserta didik paham materi dan juga membuat hatinya senang. Kondisi pembelajaran yang menyenangkan dan berkesan dapat membuat peserta didik tertarik dan berminat terlibat secara aktif, sehingga tujuan pembelajaran akan tercapai secara maksimal. Darmadi (2018) menjelaskan bahwa dalam pembelajaran menyenangkan harus berisi suasana penuh keceriaan, menyenangkan, dan yang paling utama, tidak membosankan peserta didik.

Menurut Siregar dan Hatika (2019) pembelajaran yang menyenangkan (joyfull) dapat membuat peserta didik nyaman, aman dan asyik sehingga mendorong keingintahuan yang besar untuk belajar. Yayuk dkkE. Yayuk dkk, Pembelajaran Matematika Yang Menyenangkan (Malang: Universitas Muhammadiyah Malang, 2018). menjelaskan bahwa suasana menyenangkan dapat terjadi jika peserta didik dapat berinteraksi satu sama lain dalam kelompok kecil, hubungan pendidik dan peserta didik sedemikian rupa sehingga peserta didik tidak perlu takut bertanya pada pendidik atau memberi komentar termasuk mengkritik cara pendidik mengajar.

Trinova (2012) mengungkapkan dalam pembelajaran yang menyenangkan berisi perhatian, konsentrasi yang tinggi, antusiasme, keseriusan, semangat, minat, lupa waktu. Selain itu peserta didik berani dalam beraktivitas, mempertanyakan sesuatu, tidak merasa takut melakukan sesuatu, bebas mencari obyek. Yang tidak kalah pentingnya bahwa peserta didik menunjukkan ekspresi wajah membahagiakan, bernyanyi, bertepuk tangan, senang, ceria/gembira, terlibat dengan asyik. Menurut Layyinah (2017) ada beberapa indikator dalam menciptakan pembelajaran menyenangkan yaitu: (1) menyapa peserta didik dengan ramah dan semangat; (2) menciptakan lingkungan kelas yang menarik; (3) memotivasi peserta didik; dan (4) menggunakan metode yang variatif.

Berdasarkan berbagai pendapat di atas maka disimpulkan pembelajaran dapat dikatakan menyenangkan apabila terbangun suasana belajar yang rileks, bebas dari tekanan, aman, menarik, membangkitkan minat belajar, semangat, perasaan gembira, konsentrasi tinggi serta adanya keterlibatan penuh dan perhatian dari peserta didik. Penerapan strategi pembelajaran yang menyenangkan tersebut perlu dilakukan dengan cara yang tepat. Dalam hal ini, pendidik perlu memahami kondisi dan kebutuhan peserta didik selama pembelajaran daring.

Terdapat beberapa sikap peserta didik yang beberapa diantaranya menjadi 
actual selama pembelajaran di masa pandemi Covid-19, yaitu (Budiningsih, 2005): Pertama, Disiplin; Disiplin merupakan suatu kepatuhan patuh dan tertibnya peserta didik dalam menaati peraturan. Dalam situasi pembelajaran tatap muka, peserta didik terbiasa untuk mematuhi peraturan dengan memakai seragam sesuai jadwal dan topi saat upacara bendera. Namun pada pembelajaran daring di masa pandemi Covid-19, sekalipun mereka belajar dari rumah hendaknya mereka tetap menaati peraturan seperti memakai seragam yang rapi; Kedua, Jujur; Jujur dapat terlihat pada peserta didik saat mengerjakan soal dengan sungguh-sungguh tugas dari guru. Tidak terkecuali dalam konteks pembelajaran daring. Kejujuran dalam mengerjakan ujian ataupun tugas-tugas tetap harus ditanamkan dalam diri peserta didik, meskipun guru tidak memantau mereka secara langsung; dan Ketiga Tanggung jawab; Tanggung jawab merupakan rasa yang muncul apabila guru dan peserta didik paham akan tugasnya, guru mengajar dan peserta didik mengikutinya. Tanggung jawab ini bukan hanya sebatas penyelesaian tugas sekolah, peserta didik juga dituntut bertanggungjawab atas posisinya di rumah.

\section{KESIMPULAN}

Peserta didik sangat penting posisinya dalam pendidikan meskipun masih di tingkat Taman Kanak-kanak (TK)/PAUD karena pada tahap ini merupakan pondasi awal dalam membentuk karakter dan pengetahuan awal peserta didik secara formal. Peserta didik merupakan makhluk pembelajar karena terlahir sebagai manusia dengan memiliki potensi akal untuk berfikir ilmiah atau mencari kebenaran. Secara khusus ditingkat TK tuntutan pendidikan difokuskan pada aspek pengembangan: (1) nilai agama dan moral; (2) fisik dan motorik; (3) kognitif; (4) bahasa; (5) sosial dan emosi; (6) seni.

Selama pembelajaran daring, hal yang paling utama dilakukan oleh pendidik berupa menghadirkan pembelajaran yang menyenangkan agar peserta didik dapat menerima materi pelajaran dengan baik. Terdapat beberapa sikap yang harus dimiliki oleh peserta didik selama pembelajaran di masa pandemi Covid-19 agar tetap maksimal menjalani pembelajaran daring yakni kedisiplinan, kejujuran dan tanggung jawab. Oleh karena itu artikel ini mengimplikasikan kepada para pendidik diharapkan menciptakan pembelajaran yang menyenangkan agar seluruh aspek pengembangan peserta didik dapat dimaksimalkan.

\section{DAFTAR PUSTAKA}

Abdul, K., Yulianto, E., \& Fauzy, A. (2014). Dasar-Dasar Pendidikan. Karisma Putra Utama.

Abrizah. (2021). Pembelajaran Daring dan Karakter Siswa. Artikel Guru.

Budiningsih, A. (2005). Belajar dan Pembelajaran. Bumi Aksara. 
Danim, S. (2013). Perkembangan Peserta Didik. Alfabeta.

Darmadi, H. (2018). Optimalisasi Strategi Pembelajaran. Guepedia.

Desmita. (2009). Psikologi Perkembangan Peserta Didik. Remaja Rosdakarya.

Duraku, Z. H., \& Hoxha., L. (2020). The impact of COVID-19 on higher education: $A$ study of interaction among students' mental health, attitudes toward online learning, study skills, and changes in students' life. University of Prishtina "Hasan Prishtina": Faculty of Philosophy, Department of Psychology.

Fuadi. (2013). Peran Akal Menurut Pandangan Al-Ghazali. Jurnal Substantia, 15(1).

Kapasia, N., Paul, P., Roy, A., Saha, J., Zaveri, A., Mallick, R., Barman, B., Das, P., \& Chouhan, P. (2020). Impact of lockdown on learning status of undergraduate and postgraduate students during COVID-19 pandemic in West Bengal, India. Journal Pre-Proofs: Children and Youth Services Review. https://doi.org/10.1016/j.childyouth.2020.105194

Kompasiana. (2019). Penerapan 4C's dalam Pembelajaran. Kompasiana.Com.

Layyinah, L. (2017). Menciptakan Pembelajaran Fun Learning Based on Scientific Approach dalam Pembentukan Karakter Peserta Didik pada Pembelajaran PAl. Tarbawy, 4(1), 1-9.

Menteri Pendidikan dan Kebudayaan Republik Indonesia. (2014). Lampiran I Peraturan Menteri Pendidikan Dan Kebudayaan Republik Indonesia Nomor 137 Tahun 2014 Tentang Standar Nasional Pendidikan Anak Usia Dini Standar Isi Tentang Tingkat Pencapaian Perkembangan Anak.

Muhammad, I. (1997). Dimensi Anak. JPI. Fakultas tarbiyah UII. Vol 3 tahnun.

Mutahhari, M. (2005). Konsep Pendidikan Islami. Iqra Kurnia Gemilang.

Nata, A. (2009). Perspektif Islam tentang Strategi Pembelajaran. Kencana.

Purwanto, A., Pramono, R., Asbari, M., Santoso, P. B., Wijayanti, L. M., Hyun, C. C., \& Puri, R. S. (2020). Studi Eksploratif Dampak Pandemi Covid-19 terhadap Proses Pembelajaran Online di Sekolah Dasar. Journal of Education, Psychology and Counseling, 2(1), 1-12.

Saifuddin. (2014). Pengelolaan Pembelajaran Teoretis dan Praktis. Deepublish.

Septikasari, R., \& Frasandy, R. N. (2018). Keterampilan Abad 21 dalam Pembelajaran Pendidikan Dasar. Jurnal Tarbiyah Al-Awlad, VIII(02), 112-122.

Siregar, P. S., \& Hatika, R. G. (2019). Ayo Latihan Mengajar: Implementasi Kurikulum 2013 di Sekolah Dasar (Peerteaching dan Microteaching). Deepublish.

Sudjana, N. (2009). Penialain Hasil Proses Belajar Mengajar. Remaja Rosdakarya. 
Susanto. (2009). Pemikiran Pendidikan Islam. Sinar Grafika Offset.

Trinova, Z. (2012). Hakikat Belajar dan Bermain Menyenangkan Bagi Peserta Didik. Jurnal Al-Ta'lim, 1(3), 209-215.

Umar, L. M., \& Nursalim, M. (2020). Studi Kepustakaan tentang Dampak Wabah Covid-19 terhadap Kegiatan Belajar Mengajar pada Siswa Sekolah Dasar (SD). Jurnal BK UNESA, 11(4), 599-609.

Uno, H. B. (2006). Orientasi baru dalam Psikologi Pembelajaran. Jakarta: Bumi Aksara.

Yayuk, E., Ekowati, D. W., Suwandayani, B. I., \& Ulum, B. (2018). Pembelajaran Matematika yang Menyenangkan. Universitas Muhammadiyah Malang. 